\title{
INCLINOMETER MONITORING SYSTEM FOR STABILITY ANALYSIS: THE WESTERN SLOPE OF THE BEŁCHATÓW FIELD CASE STUDY
}

\author{
MAREK CAŁA, JOANNA JAKÓBCZYK, KATARZYNA CYRAN \\ AGH University of Science and Technology, Al. Mickiewicza 30, 30-059 Kraków, Poland, \\ Phone: +48 1261746 95, e-mail: joanna.jakobczyk@agh.edu.pl,kcyran@agh.edu.pl)
}

\begin{abstract}
The geological structure of the Bełchatów area is very complicated as a result of tectonic and sedimentation processes. The long-term exploitation of the Bełchatów field influenced the development of horizontal displacements. The variety of factors that have impact on the Bełchatów western slope stability conditions, forced the necessity of complex geotechnical monitoring. The geotechnical monitoring of the western slope was carried out with the use of slope inclinometers. From 2005 to 2013 fourteen slope inclinometers were installed, however, currently seven of them are in operation. The present analysis depicts inclinometers situated in the north part of the western slope, for which the largest deformations were registered. The results revealed that the horizontal displacements and formation of slip surfaces are related to complicated geological structure and intensive tectonic deformations in the area. Therefore, the influence of exploitation marked by changes in slope geometry was also noticeable.
\end{abstract}

Key words: slope inclinometer, geotechnical monitoring, horizontal displacement analysis, the exploitation influence, Betchatów open pit mine

\section{INTRODUCTION}

The necessity of geotechnical monitoring in the western slope of the Bełchatów field was outlined mainly by the long term exploitation, which had an impact on slope stability conditions. The extension of exploitation to the deeper levels, drainage processes as well as complicated geological structure in the vicinity of the Bełchatów mining field contributed to the development of deformations [1], [5], [8]. The observations were conducted to detect zones of deformations and determine if movement is constant or accelerating.

Geotechnical monitoring of the western slope was carried out with the use of slope inclinometers. The inclinometer device is designed to be applied for slope deformation observation as well as dynamic control, assessment and forecasting of landslides [3], [18], [20]. The slope inclinometer device is used to determine the magnitude, rate, direction, depth and type of landslide movement [22]. It measures deformation normal to the axis of the borehole casing, which provides a profile of subsurface horizontal deformation. Moreover, the depth at which shear movement is detected by the slope inclinometer is the depth of the failure surface [6], [9], [10], [22].
The aim of the borehole monitoring in the western slope of Bełchatów field was to measure the displacement values and their increments as with the function of the hole depth. The points movement trajectory on selected levels, their velocities, the azimuth of the inclinometer pipe rotation were also analysed. All these measurements were designed to locate the depth of the potential slip surface and examine the direction of the deformation development [6], [7], [15], [18], [19].

\section{OUTLINE OF THE BEŁCHATÓW FIELD AND ITS WESTERN SLOPE GEOLOGY}

The lignite (brown coal) deposit in the Bełchatów area was formed in a narrow $2.5-3 \mathrm{~km}$ long depression called the Kleszczów Graben. The Kleszczów Graben extends between Pilica and Warta rivers at a distance of over $80 \mathrm{~km}$. It is a segmented and subsided tectonic structure limited by vertical faults dipping at an angle of about $80-90^{\circ}$. The Kleszczów Graben was formed as a result of faulting in Alpine phase (Early Miocene) and filled with coal bearing sediments [4], [12], [21]. 
The Bełchatów lignite deposit is naturally divided into two parts by the presence of the Dębina salt dome: the Bełchatów and the Szczerców mining fields. The Bełchatów mining field is situated in the central part of the Kleszczów Graben (Fig. 1) between the Dębina salt dome (on the west) and Widawka fault (on the east) [11], [16], [21], [25].
The oldest sediments in the Bełchatów area are represented by evaporates (Zechstein cyclothem PZ1) that build the Dębina salt dome. The coal formation is underlaid by Mesozoic marls, sandstones, limestones, muds and sands. The Tertiary strata was subdivided into four lithostratigraphic complexes: subcoal, coal, clay-coal and clay-sand [16]. The Quaternary sedi-

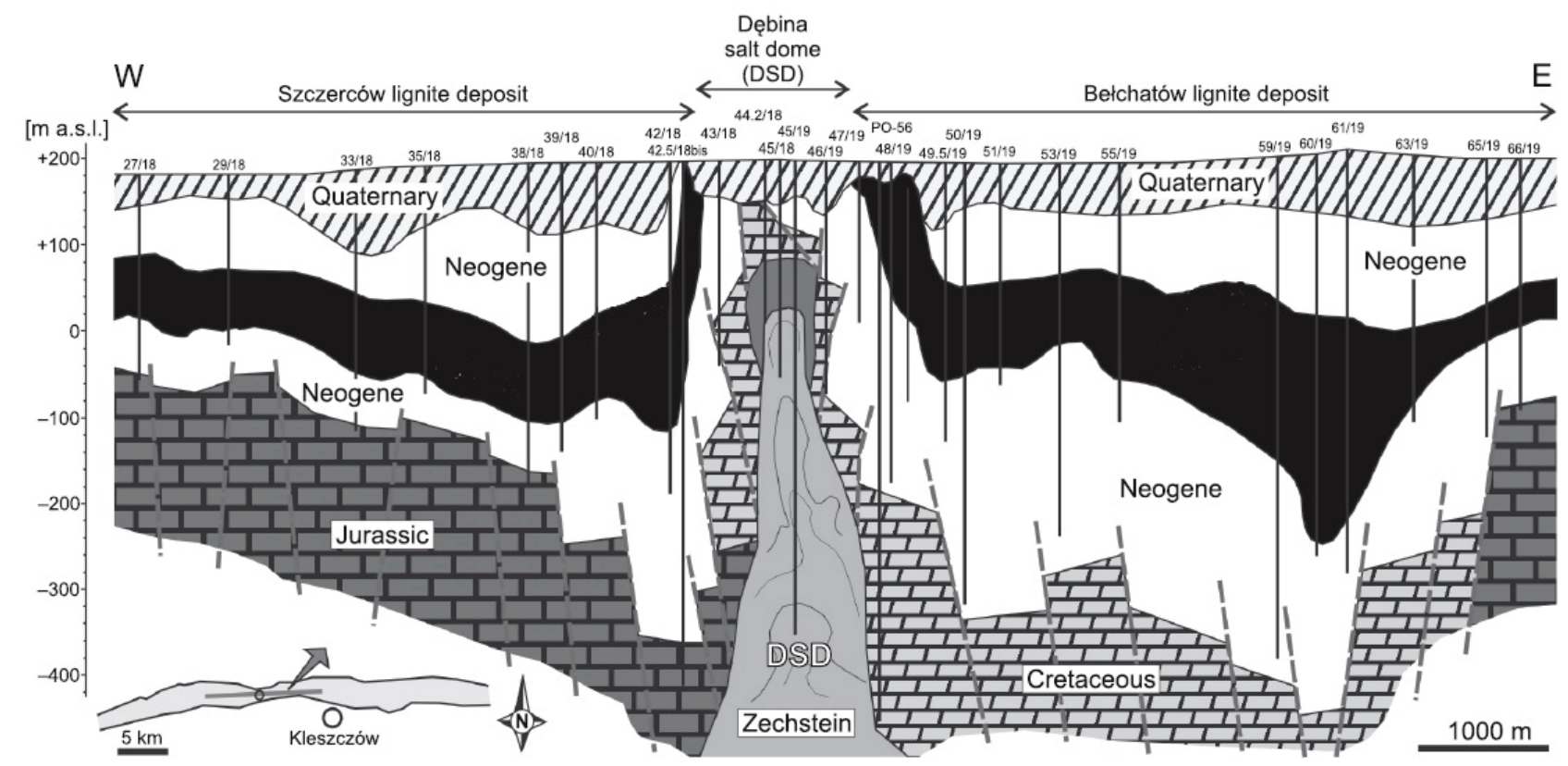

Fig. 1. Geological structure of the Bełchatów coal deposit (after [13], [23])

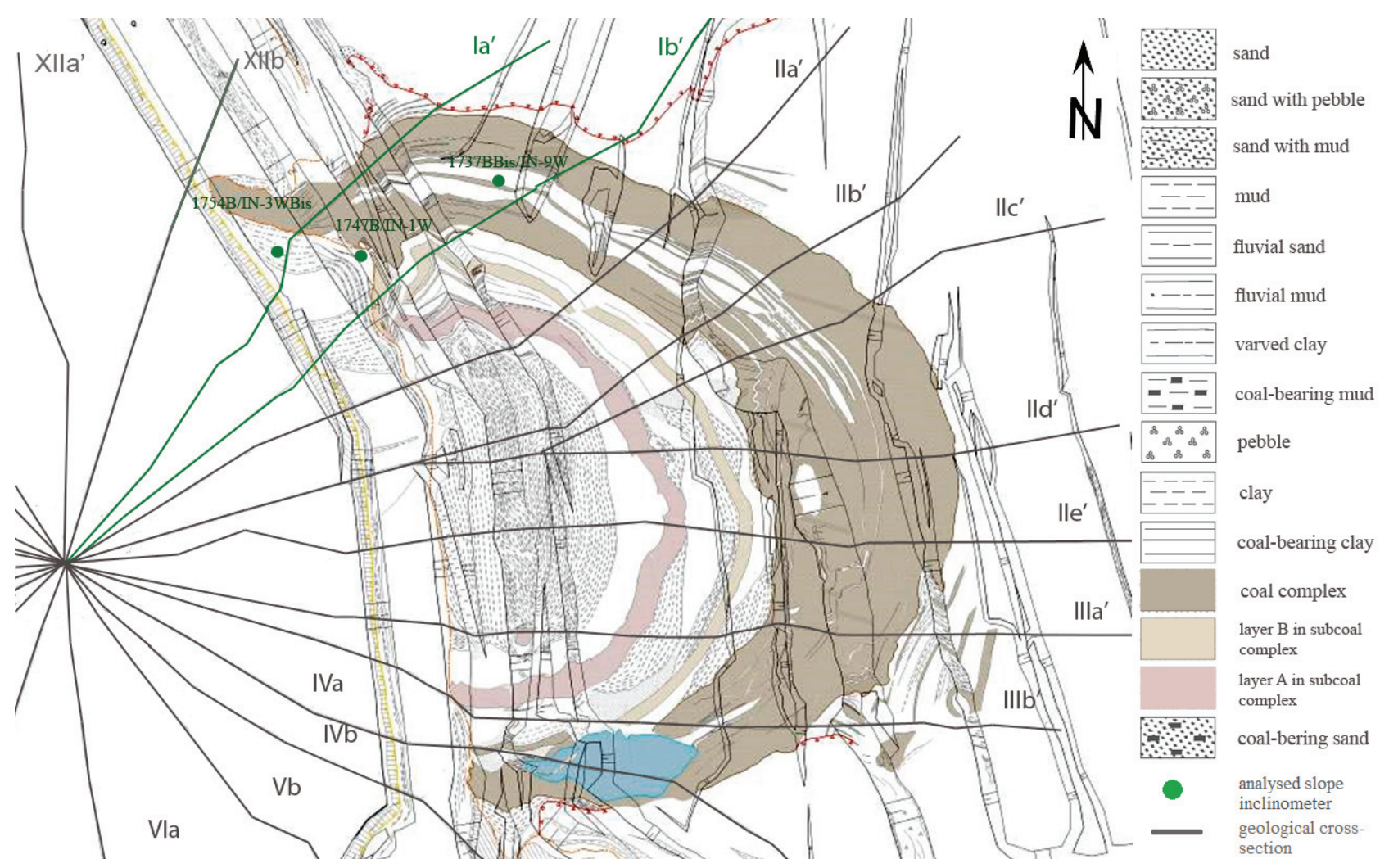

Fig. 2. The main anticline in the Bełchatów mining field (after [17]) 
ments are represented by sands, muds and clays [11], [16], [21], [24], [25].

The geological structure of the western slope is connected with the presence of the salt dome. The coal bearing formation was folded, dislocated and brecciated as a result of compression, bending and flowing connected with formation of the salt dome [14]. The main structure in this area is an anticline built of coal and subcoal complexes (Fig. 2). The axis plane of the anticline is tilted at an angle of $30^{\circ}$ on the east [4].

\section{THE MONITORING OF SUBSURFACE DISPLACEMENTS}

\subsection{SLOPE INCLINOMETER MEASUREMENTS}

Generally, the measurements of the horizontal displacement along various points on a borehole are executed in three steps [6], [9]:

- the first step - the measurement with noninstrumented probe, aimed to check the borehole patency,

- the second step - the measurement with instrumented probe in the A-A reference direction (the direction of probable maximum displacement),

- the third step - the measurement with instrumented probe in the B-B reference direction perpendicular to A-A.

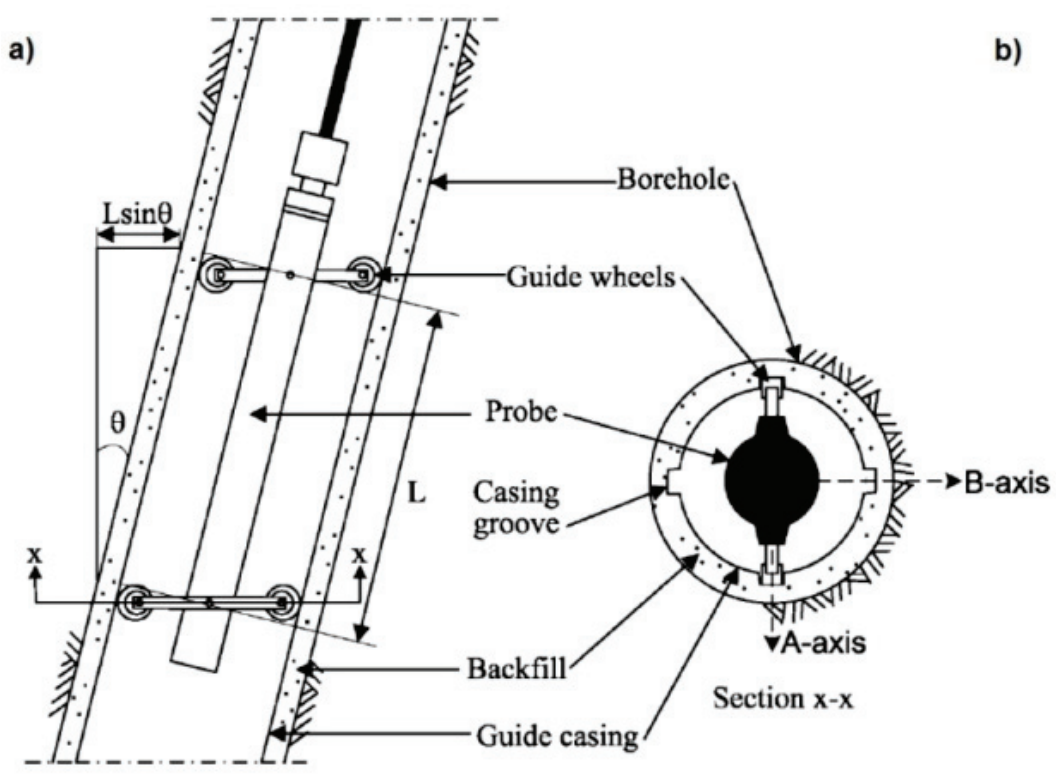

The inclinometer probe does not provide horizontal movement of the casing directly. The probe measures the tilt of the casing which can be converted to a horizontal movement (Fig. 3). The angle $\theta$ is the angle of tilt measured by the inclinometer probe, and $L$ is the measurement interval. The deviation from vertical is determined by the sine function and expressed as follows [6], [9], [22]

$$
\text { deviation from vertical }=L \cdot \sin \theta \text {. }
$$

Furthermore, the total horizontal displacement is achieved by summing up the individual lateral deviations from the bottom of the casing to the top. The summation process is described in Fig. 3 and could be shown as

$$
\sum L_{i} \sin \theta
$$

\subsection{THE SUBSURFACE DEFORMATION ANALYSIS}

The slope inclinometers were installed in 2005, when Ist level of the Bełchatów western slope was made at the coordinate of $+198 /+176$ m.a.s.l. Along with the exploitation progress some of the inclinometers were abandoned and new were installed. From 2005 to 2013 fourteen measuring positions were located (Fig. 4, Table 1) on the western slope - currently seven slope inclinometers are still active [5].

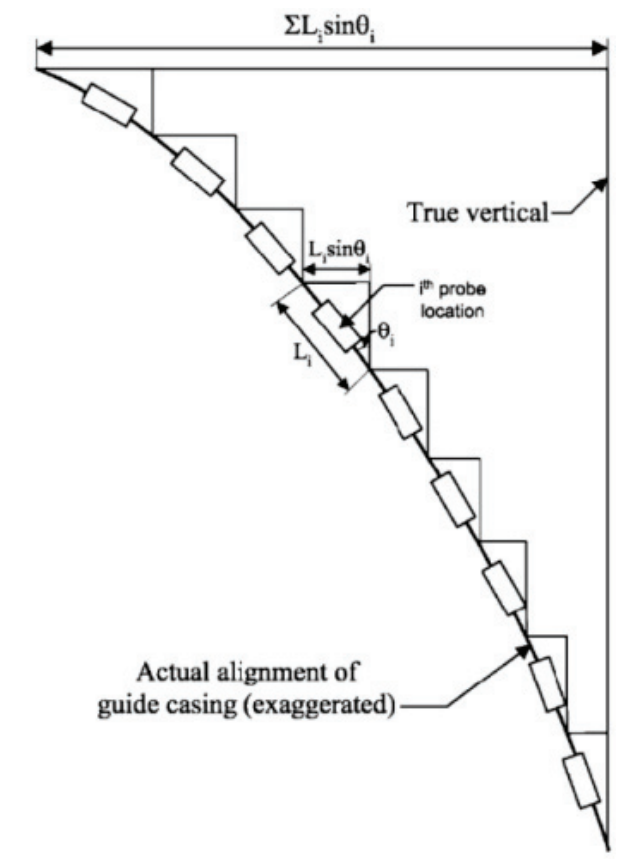

Fig. 3. Schematic of the slope inclinometer: (a) inclinometer device, (b) illustration of operation (based on [6], [22]) 


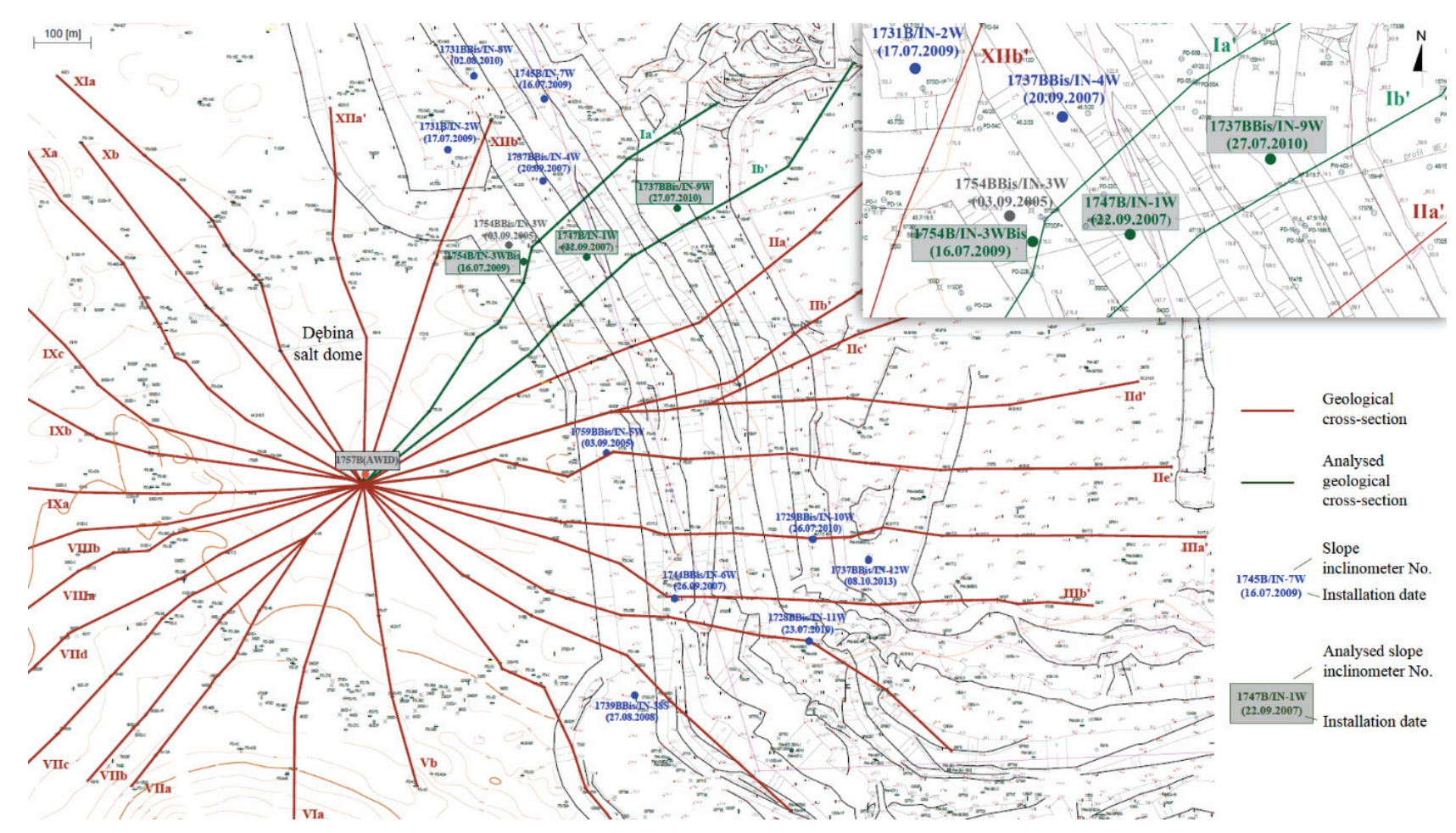

Fig. 4. The slope inclinometers distribution and location of cross-sections in the Bełchatów western slope (based on [2])

Table 1. The basic information about inclinometers installed on the Bełchatów western slope (based on [2])

\begin{tabular}{|l|c|c|c|c|c|}
\hline \multicolumn{1}{|c|}{ Inclinometer No. } & $\begin{array}{c}\text { Installation } \\
\text { date }\end{array}$ & $\begin{array}{c}\text { Installation level } \\
{[\mathrm{m} . \mathrm{a} . \mathrm{s} .1 .]}\end{array}$ & $\begin{array}{c}\text { Depth } \\
{[\mathrm{m}]}\end{array}$ & $\begin{array}{c}\text { The hole bottom } \\
\text { level [m.a.s.l.] }\end{array}$ & $\begin{array}{c}\text { The latest } \\
\text { measurement date }\end{array}$ \\
\hline $\mathbf{1 7 4 7 B / I N - 1 W}$ & $\mathbf{2 2 . 0 9 . 2 0 0 7}$ & $\mathbf{+ 1 4 7 . 9}$ & $\mathbf{1 1 2 . 0}$ & $\mathbf{+ 3 5 . 9}$ & $\mathbf{2 5 . 0 5 . 2 0 1 1}$ \\
\hline 1731B/IN-2W & 17.07 .2009 & +176.0 & 110.0 & +66.0 & 22.02 .2010 \\
\hline 1754BBis/IN-3W & 03.09 .2005 & +176.1 & 92.0 & 84.1 & 05.06 .2008 \\
\hline 1754B/IN-3WBis & $\mathbf{1 6 . 0 7 . 2 0 0 9}$ & $+\mathbf{1 7 7 . 0}$ & $\mathbf{1 6 0 . 5}$ & $+\mathbf{1 6 . 5}$ & $\mathbf{1 6 . 0 1 . 2 0 1 4}$ \\
\hline 1737BBis/IN-4W & 20.09 .2007 & +148.3 & 70.0 & +78.3 & 18.05 .2012 \\
\hline 1759BBis/IN-5W & 03.09 .2005 & +175.98 & 66.5 & +109.48 & 20.12 .2007 \\
\hline 1744BBis/IN-6W & 26.09 .2007 & +148.3 & 112.5 & +35.8 & 17.01 .2014 \\
\hline 1745B/IN-7W & 16.07 .2009 & +122.5 & 49.5 & +73.0 & 22.01 .2014 \\
\hline 1731BBis/IN-8W & 02.08 .2010 & +148.4 & 117.5 & +30.9 & 22.01 .2014 \\
\hline 1737BBis/IN-9W & $\mathbf{2 7 . 0 7 . 2 0 1 0}$ & $+\mathbf{8 8 . 4}$ & $\mathbf{1 0 2 . 0}$ & $-\mathbf{1 3 . 6}$ & $\mathbf{2 2 . 0 1 . 2 0 1 4}$ \\
\hline 1729BBis/IN-10W & 26.07 .2010 & +74.0 & 101.0 & -27.0 & 08.05 .2013 \\
\hline 1728BBis/IN-11W & 23.07 .2010 & +109.1 & 80.5 & +28.6 & 17.01 .2014 \\
\hline 1737BBis/IN-12 & 08.10 .2013 & +60.0 & 80.5 & -20.5 & 09.11 .2010 \\
\hline 1739BBis/IN-38S & 27.08 .2008 & +175.5 & 90.5 & +85.0 & 17.01 .2014 \\
\hline
\end{tabular}

The analysis of measurements from three inclinometers (in gray in Table 1) is described below. The inclinometers are situated in the north part of the western slope, for which the largest deformations were registered. They were also installed on different mining levels, however arranged to form approximately one line (Figs. 4, 5, 6). Consequently, it is possible to evaluate the slip surface location across the entire western slope from SW to NE direction.
Geological situation in the analysed region is outlined in cross-sections Ia' and Ib' (in green in Fig. 4 and Figs. 5, 6). The total horizontal displacement values as a function of the pipe depth for each inclinometer are presented in graphs (Figs. 7, 9, 11). Results shown in graphs were correlated with the geological profiles. The aim of the analysis was to identify the potential slip surface levels and the direction of the possible further movement. 


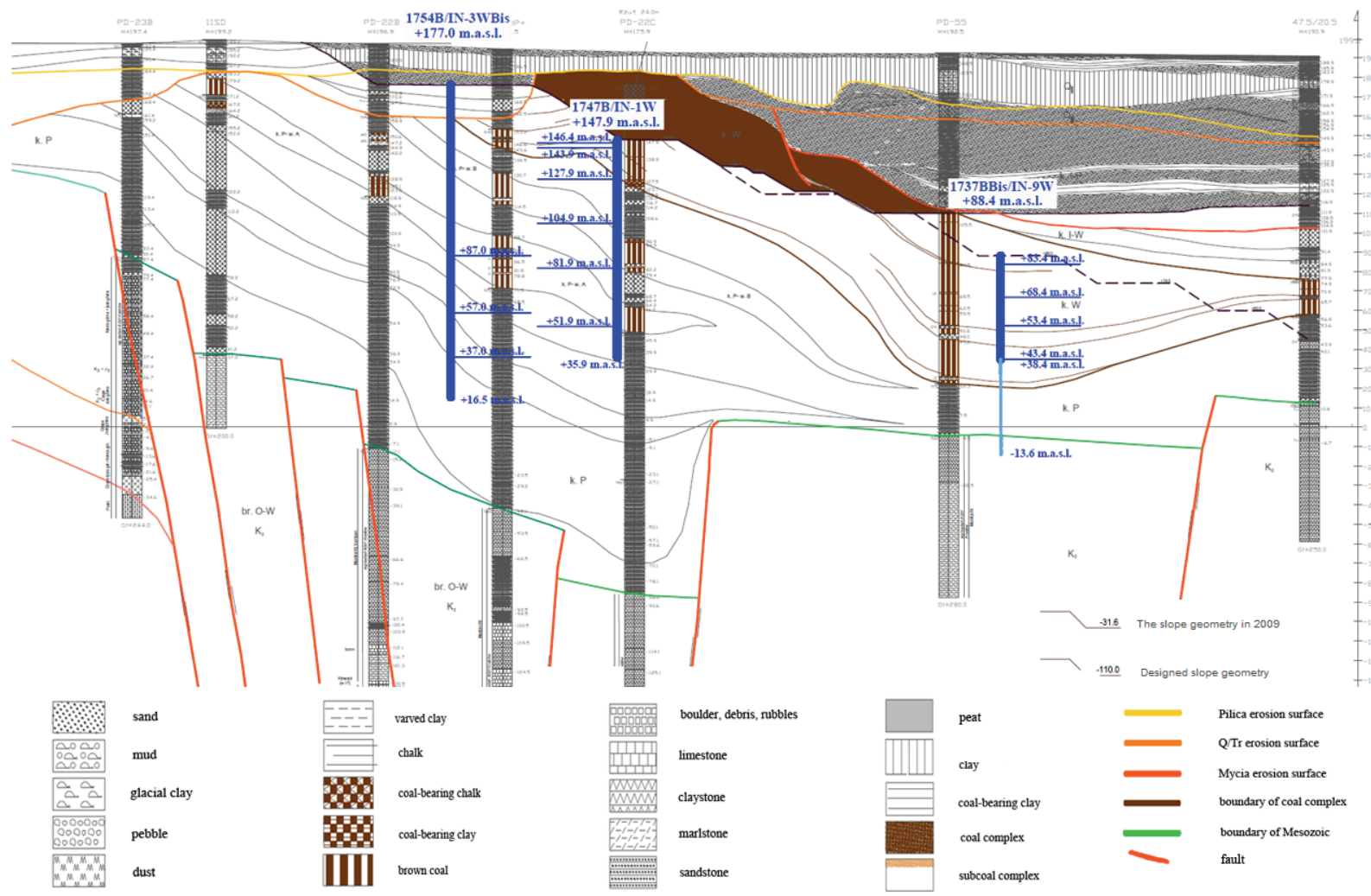

Fig. 5. The Ia' geological cross-section of the Bełchatów western slope with the location of the inclinometers No.: 1754B/IN-3WBis, 1747B/IN-1W, 1737BBis/IN-9W (based on [2])

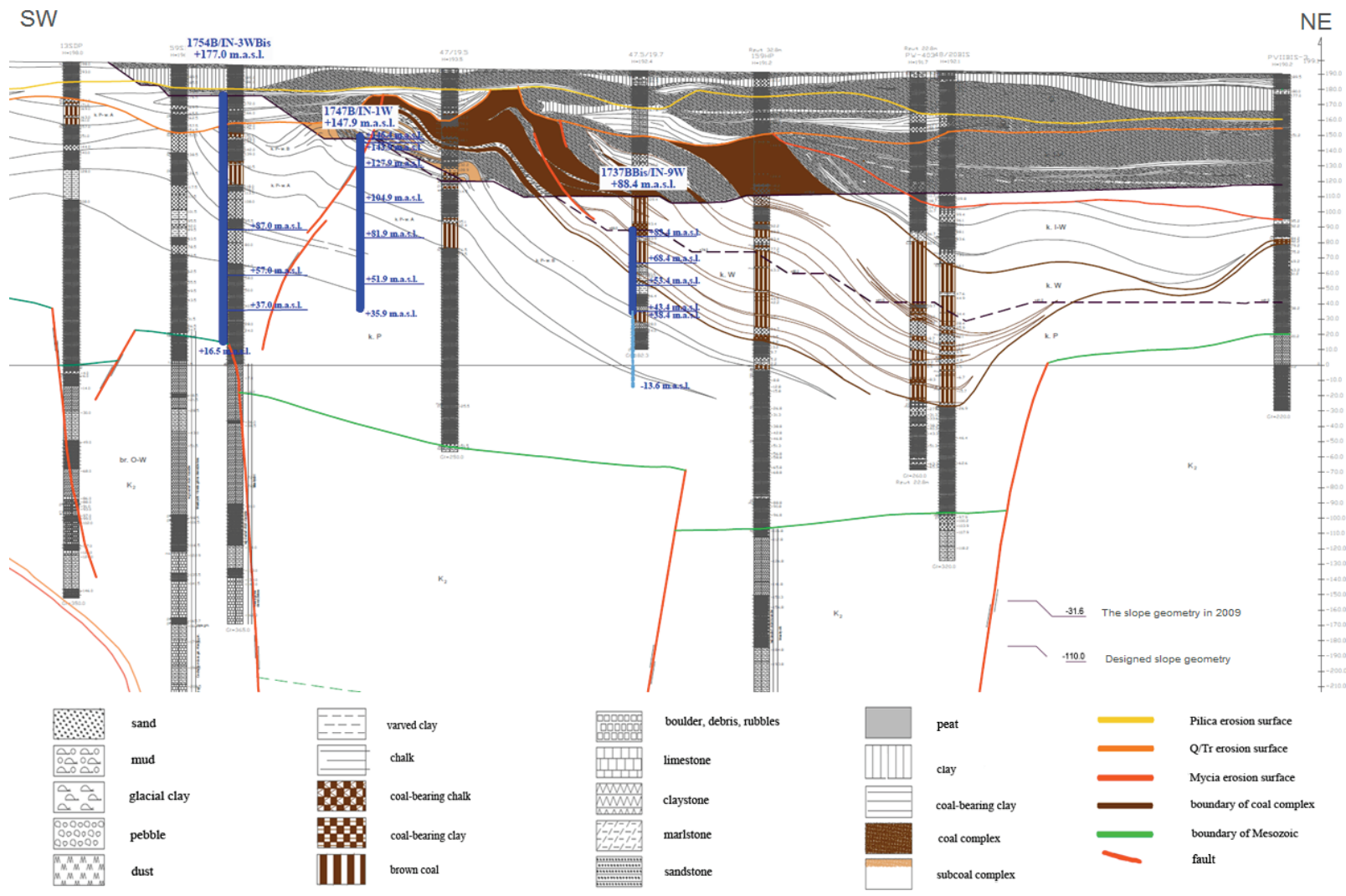

Fig. 6. The Ib' geological cross-section of the Bełchatów western slope with the location of the inclinometers No.: 1754B/IN-3WBis, 1747B/IN-1W, 1737BBis/IN-9W (based on [2]) 
$1747 B / I N-1 W$-identification of the potential slip surface

The inclinometer No. 1747B/IN-1W was installed in September 2007 from IInd level of the western slope +147.9 m.a.s.l. with initial depth of 112.0 meters. The increase in values of the horizontal displacement indicated six potential slip surfaces on the following levels (Fig. 7):

- +146.4 m.a.s.1. - corresponds to the depth of 1.5 meters below the installation level and can be connected with the presence of very thin clay layer in coal complex as well as fault plane (Fig. 6),

- +143.9 m.a.s.l. - corresponds to the depth of 4.0 meters below the installation level and can be connected with the presence of very thin clay layer in coal complex,

- +127.9 m.a.s.l. - corresponds to the depth of 20.0 meters below the installation level and the presence of the 2.4 meter thick coal-bearing clay which underlaid coal layer separating coal complex from subcoal complex,

- +104.9 m.a.s.1. - corresponds to the depth of 43.0 meters below the installation level and can be connected with the presence of the 2.0 meter thick coal-bearing clay which underlaid coal layer,

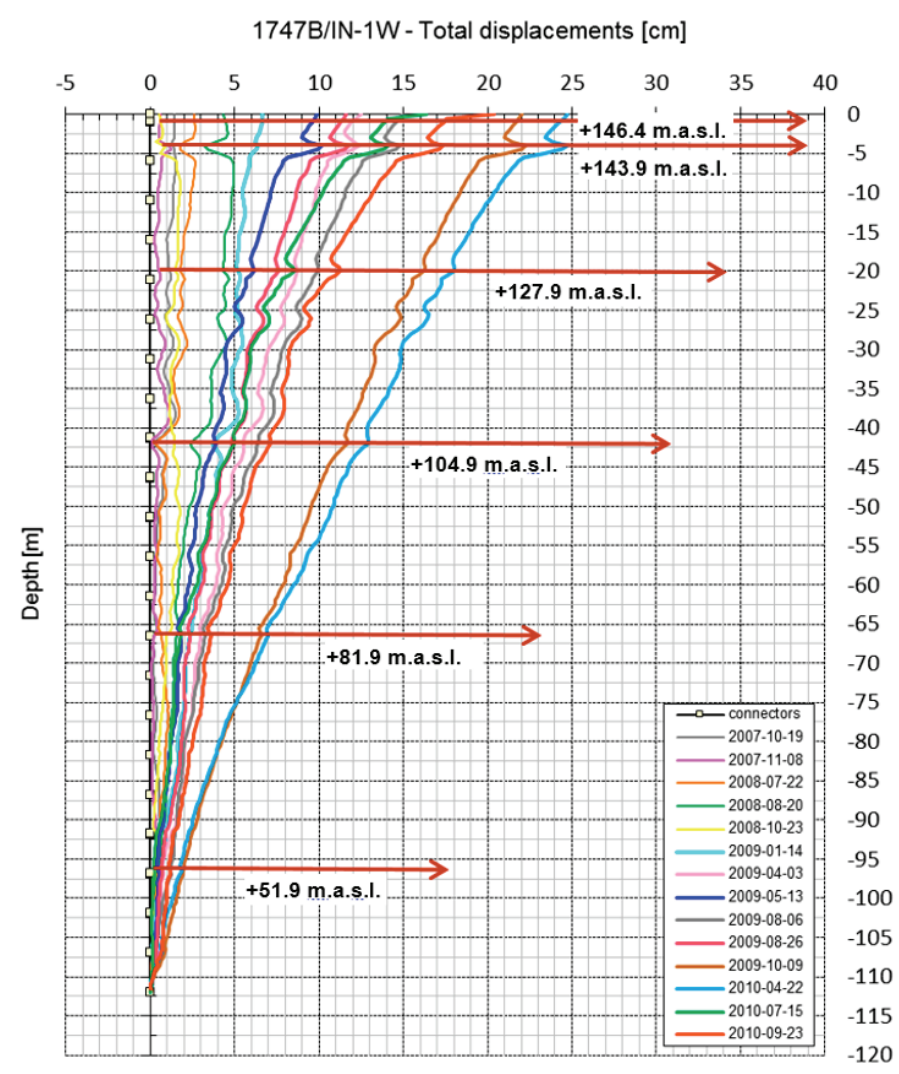

- +81.9 m.a.s.1. - corresponds to the depth of 66.0 meters below the installation level and the presence of the 2.8 meter thick coal layer underlaid and overlaid by mud layers,

- +51.9 m.a.s.l. - corresponds to the depth of 96.0 meters below the installation level and the presence of the coal layer.

The last measurement for the inclinometer No. 1747B/IN-1W was conducted in 25.05.2011, when the guide casing was cut at a depth of 1.5 meter below the installation level. During the measurement period the largest deformations were observed on the surface, where total displacements reached values of c.a. 25.0 [cm] between September 2007 and April 2010. Moreover, the depth of the slip surface occurrence is related to fault plane location.

The analysis of the geology in the vicinity of the inclinometer borehole was necessary in order to explain the possible mechanism of slip surface formation. The coal layer has a stiffness different from surrounded sediments. It also has a low density (c.a. $1100-1600 \mathrm{~kg} / \mathrm{m}^{3}$ ) and high moisture content (even c.a. $120 \%$ ). All of these factors give favourable conditions to the occurrence of the slip surface. The presence of the clay and coal-bearing clay layers encourages the most favorable conditions for slip surface

Fig. 7. The total horizontal displacements measured in inclinometer 1747B/IN-1W and the geological profile with potential slip surfaces levels (based on [2]) 
formation. The internal texture of clay minerals made them susceptible to effects of the soil dumping. Owing to this, the presence of clay layer should be identified with the high possibility of the potential slip surface location.

The influence of the exploitation progress on the deformations observed in inclinometer No. 1747B/IN-1W was noticed. A significant change of the slope geometry in the analysed region took place between September 2007 and April 2010. In this period north part of the IInd mining level (from the depth of $+176 /+146$ m.a.s.l.) and the IIIrd mining level (from the depth of $+148 /+120 /+110$ m.a.s.1.) as well as the IVth mining level (from the depth of $+110 /+90 /+76$ m.a.s.l.) had been excavated. The geometry change determined a significant increase in value of the total horizontal displacement measured by inclinometer No. $1747 \mathrm{~B} / \mathrm{IN}-1 \mathrm{~W}$, it reached $25.0 \mathrm{~cm}$ on the ground surface level and at a depth of 4.0 meters below the installation level (Fig. 7). In addition, it can be noticed that all potential slip surfaces were correlated with the mining activities on certain levels (Figs. 5, 6, 8):

- $\quad+146.4$ m.a.s.l. - IInd/IIIrd mining level +148 m.a.s.l.

- +127.9 m.a.s.l. - IIIrd mining level +120 m.a.s.l.
- $\quad+104.9$ m.a.s.l. - IIIrd mining level +120/+110 m.a.s.l.

- $\quad+81.9$ m.a.s.l. - IVth mining level +90/+76 m.a.s.l.

\section{B/IN-3WBis - identification of the potential slip surface}

Three potential slip surfaces, for the inclinometer No. 1754B/IN-3WBis (installed in July 2009 from Ith level of western slope +177.0 m.a.s.l. with initial depth of 160.5 meters), were indicated (Fig. 9):

- +87.0 m.a.s.1. - corresponds to the depth of 90.0 meters below the installation level and the presence of the bottom of the coal layer,

- +57.0 m.a.s.1. - corresponds to the depth of 120.0 meters below the installation level and the presence of the sand layer,

- +37.0 m.a.s.1. - corresponds to the depth of 140.0 meters below the installation level and the presence of the sand layer which is limited from the eastern side by the 2nd fault of the Kleszczów Graben.

Moreover, several less visible slip surfaces at the contact between clay, coal and sand layers can be recognised between the +87.0 m.a.s.l. and the installation

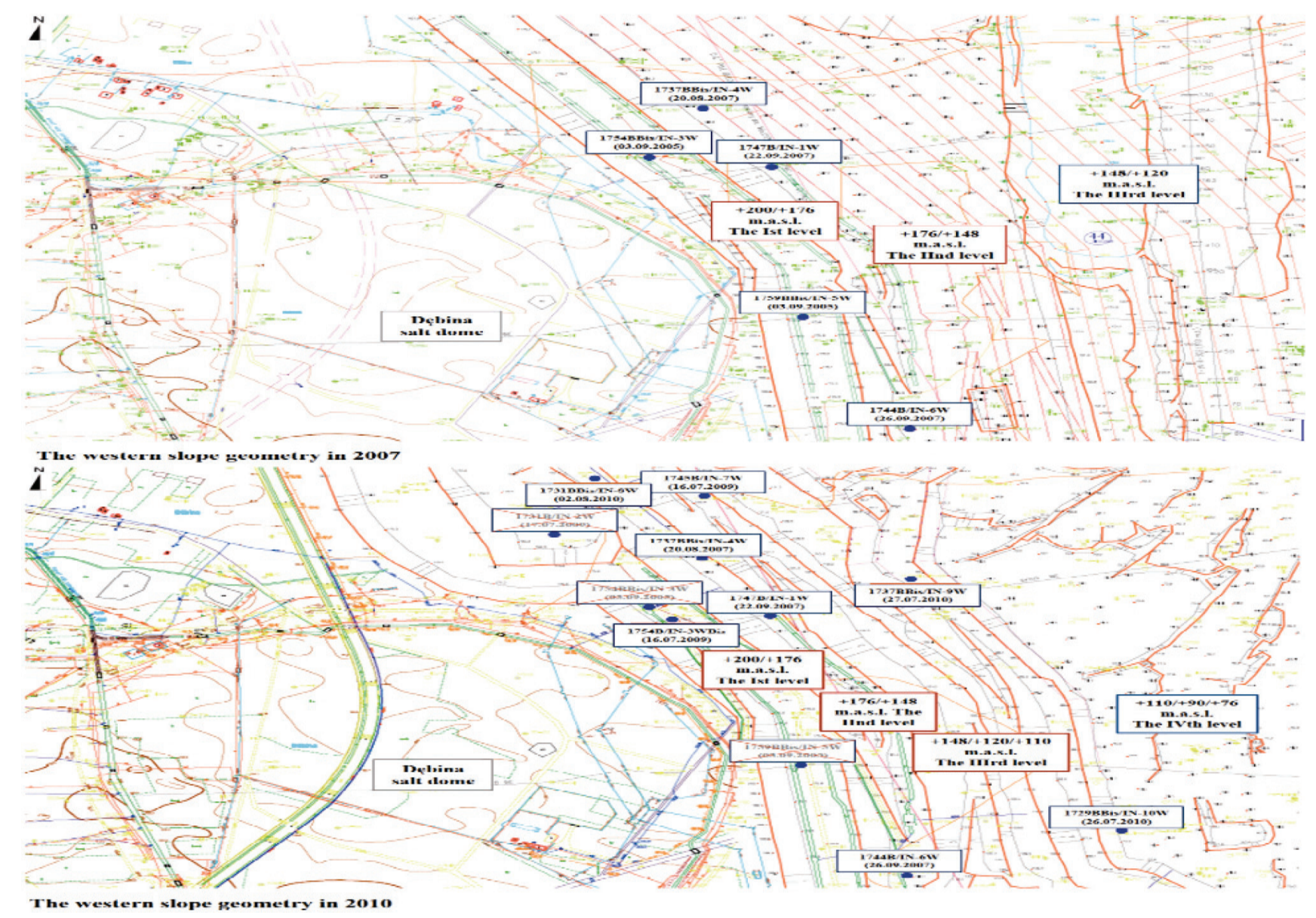

Fig. 8. The exploitation progress and western slope geometry changes between 2007 and 2010 (based on [2]) 


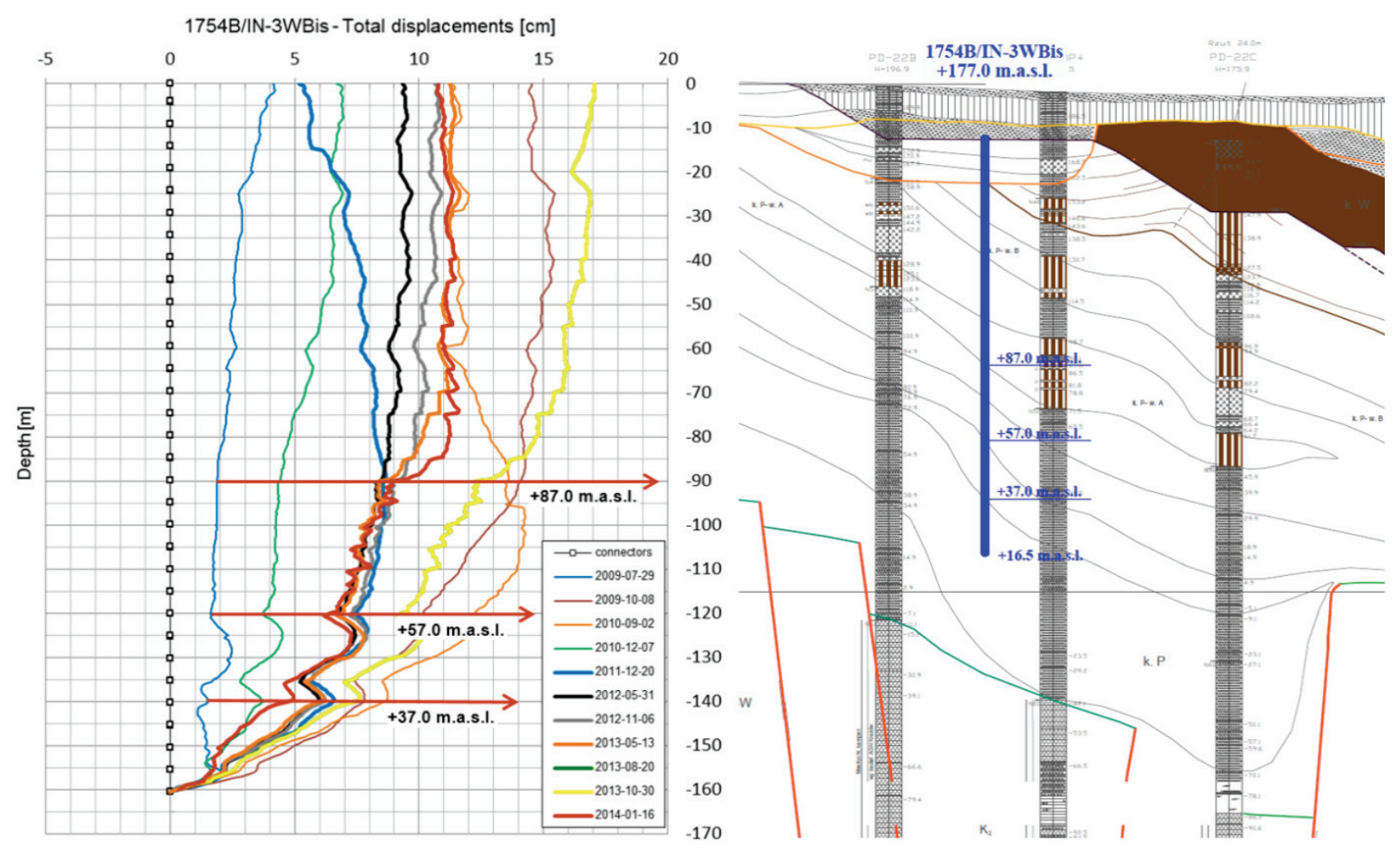

Fig. 9. The total horizontal displacements measured in inclinometer 1754B/IN-3Wbis and the geological profile with potential slip surface levels (based on [2])

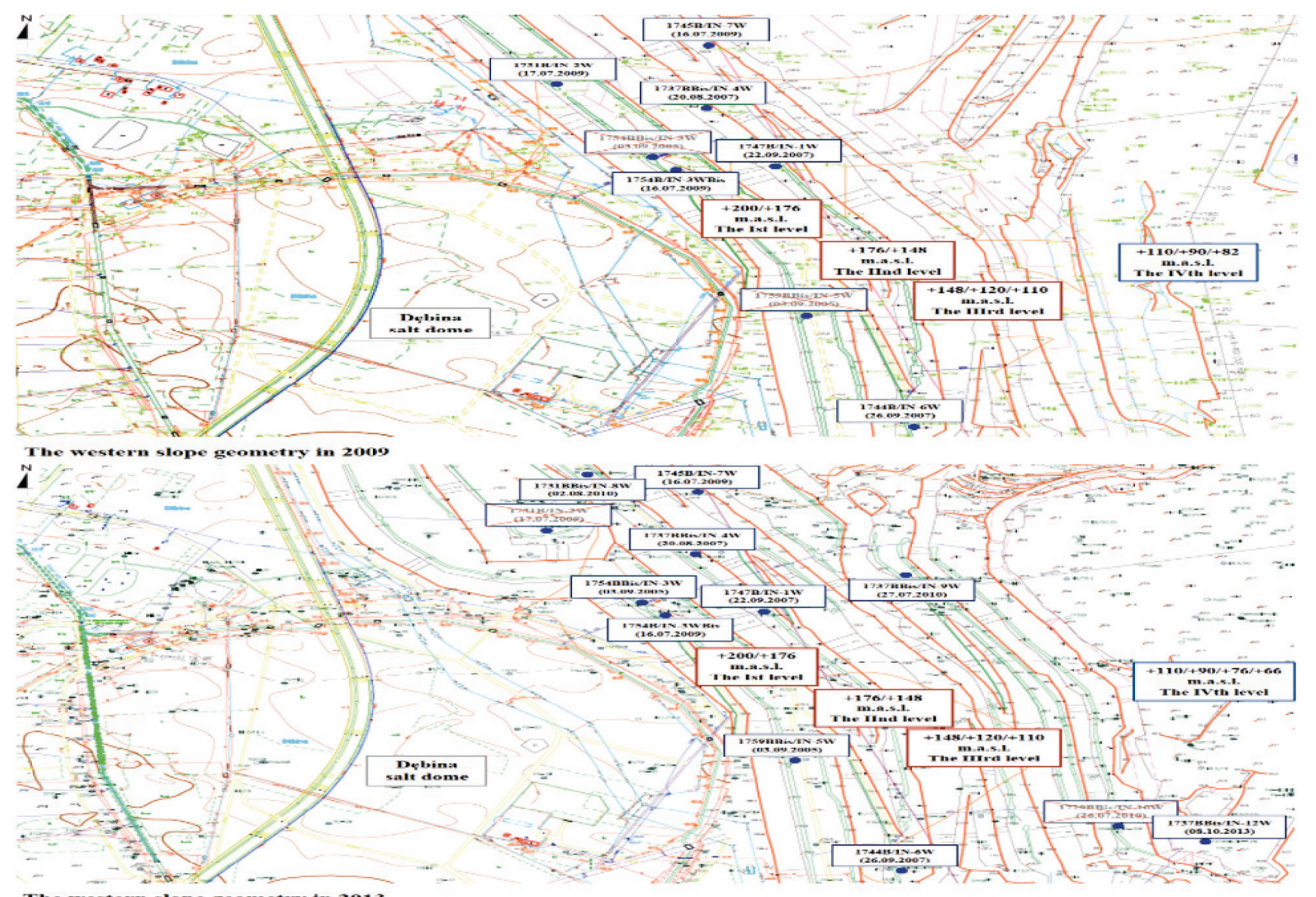

Fig. 10. The exploitation progress and western slope geometry changes between 2009 and 2013 (based on [2]) 
level. The direction of layers dipping is determined by the salt dome contour (from the SW direction) and 2nd main fault of the Kleszczów Graben (from the NE direction). All layers reflect the shape of the Cretaceous sediments, which aids the probability of landslide occurrence. As a result of tectonic deformations, sediments that filled Graben between 2nd northern (UNB No. 2) and 3rd northern main fault (UNB No. 3) are characterised by more horizontal surface, which can limit the depth of potential slip surfaces (Fig. 5).

The influence of the exploitation progress on the deformations observed in inclinometer No. 1754B/ IN-3WBis was also indicated. The significant change of the slope geometry in the north part of the western slope took place between July 2009 and October 2013. It was caused by progressing mining works on the IIIrd level and on the IVth level as well (from the depth of $+110 /+90 /+76 /+66$ m.a.s.1.). The geometry change revealed the increase in value of the total horizontal displacement measured by inclinometer No. 1754B/IN-3WBis. The displacement reached $17.0 \mathrm{~cm}$ on the ground surface level and was constant to the depth of +87.0 m.a.s.l., where potential slip surface was examined (Fig. 9). Furthermore, two potential slip surfaces for which the highest increase in displacement was noticed can be correlated with the mining activities on certain levels (Figs. 5, 6, 10):

- $\quad+87.0$ m.a.s.l. - IVth mining level $+90 /+76$ m.a.s.l.

- +57.0 m.a.s.1. - IVth mining level +66 m.a.s.1.

\section{BBis/IN-9W-identification of the potential slip surface}

The inclinometer No. 1737BBis/IN-9W installed in July 2010 from IVth level of the western slope +88.4 m.a.s.l. with initial depth of 102.0 meters, revealed four potential slip surfaces on following levels (Fig. 11):

- +83.4 m.a.s.1. - corresponds to the depth of 5.0 meters below the installation level and the presence of the contact surface between clay overlaid by coal-bearing clay,

- +68.4 m.a.s.l. - corresponds to the depth of 20.0 meters below the installation level and the presence of the contact surface between coal and clay,

- +53.4 m.a.s.1. - corresponds to the depth of 35.0 meters below the installation level and the presence of the clay layer which separates coal from subcoal complex,

- $+43.4 /+38.4$ m.a.s.l - corresponds to the depth of 45.0/50.0 meters below the installation level and the presence of the coal layer overlaid by mud layer.

The first measurement (17.09.2010) on +43.4 m.a.s.l. registered the borehole failure and since then the inclinometer is active till the depth of about 45.0 meters below the surface. Total displacements reached values of c.a. $13.0[\mathrm{~cm}]$ but the highest values were observed at c.a. 5.0 meters below the installation level, which indicates the rotational character of displacements. The rotation was caused by the downward direction of the coal layers and its rapid change near the fault surface (Fig. 6).

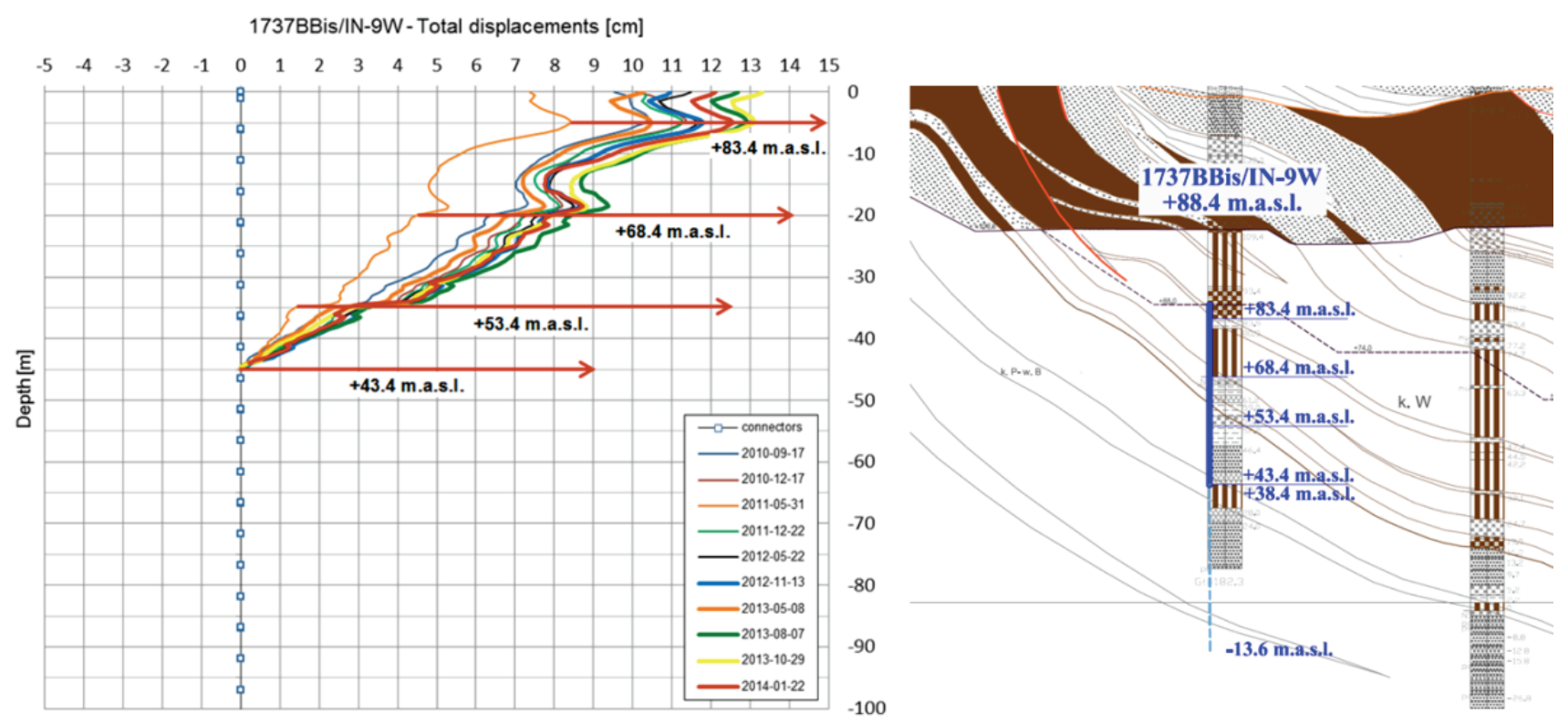

Fig. 11. The total horizontal displacements measured in inclinometer 1737BBis/IN-9W and the geological profile with potential slip surface levels (based on [2]) 
For the inclinometer No. 1737BBis/IN-9W the largest deformations were observed between July 2010 and October 2013, when total horizontal displacement reached value c.a. $13.0 \mathrm{~cm}$ on the ground surface level and at a depth of 5.0 meters below the installation level, where potential slip surface was examined (Fig. 11). Moreover, between May 2011 and October 2013 the total horizontal displacement reached value $6.0 \mathrm{~cm}$ on the ground surface level. Furthermore, it should be pointed out that two potential slip surfaces for which the highest increase in displacement was noticed are correlated with the mining activities on certain levels (Figs. 5, 6, 10):

- $\quad+83.4$ m.a.s.1. - IVth mining level +90/+76 m.a.s.1.

- $\quad+68.4$ m.a.s.l. - IVth mining level +66 m.a.s.l.

\section{CONCLUSIONS}

The data examined showed that horizontal displacements are strongly associated with the complicated geological structure and intensive tectonic deformations in the area of the Bełchatów mining field. The maximum value of the total displacement registered in the western slope area between 2007 and 2010 reached c.a. $25 \mathrm{~cm}$ and was related to the occurrence of the fault plane. The analysis of measurement results revealed that fault zones are more prone to formation of slip surfaces. Moreover, the potential slip surfaces were mainly registered in coal, coal-bearing clay and clay layers. The formation of slip surfaces is connected with the difference in density and stiffness between coal layers and surrounded sediments. Nevertheless, the influence of exploitation displayed by changes in the slope geometry was also noticeable.

Factors described above have impact on the western slope stability conditions. Conducted observations enabled detection of movements and determination of the movement activity. Therefore, further geotechnical monitoring of the western slope in the Bełchatów mining field is recommended, particularly in the light of plans connected with the extension of exploitation to the deeper levels.

\section{REFERENCES}

[1] CaŁa M., Flisiak J., RYBICKI S., Geotechnical hazards from rheological processes in the salt dome Dębina in the light of numerical modelling, [in:] D. Flisiak (ed.), Geotechnics and civil engineering 2004: XXVII Winter School of Rock Mechanics, Zakopane, 14-19 March 2004, Wydawnictwo KGBiG AGH, 2004, 23-35.
[2] Cala M., Flisiak D., Flisiak J., Kowalski M., JakóbczyK J., Szczerców field. Analysis of change in salt dome deformations as a result of brown coal exploitation from non-economic resources in Dębina salt dome area, AGH University of Science and Technology Cracow, unpublished, 2014.

[3] Carri A., Chiapponi L., Giovanelli R., Spaggiari L., SEGALINI A., Improving landslide displacement measurement through automatic recording and statistical analysis, Procedia Earth and Planetary Science, 2015, 15, 536-541.

[4] Ciuk E., Tectonics of the Kleszczów Graben and its impact on the origin of brow coal deposit, [in:] W. Barczyk (ed.), Guide of LII Polish Geological Society Conference Bełchatów, 11-14 September 1980, Geological Publication, Warsaw, 1980, 38-55.

[5] Czarnecki L., Organiściak B., Krywult Ł., Chrost A., Stability of the western slope in Betchatów open-pit cast in a light of geological observations and geotechnical measurements with inclusion of Dębina salt dome, Górnictwo i Geoinżynieria, 2010, 34, 173-182.

[6] DunNiclifF J., GreEN G.E., Geotechnical Instrumentation for Monitoring Field Performance, John Wiley, New York, 1988.

[7] Dunnicliff J., LaFonta J.G., In-Place Inclinometers: A Significant Test Program, Geotechnical News, March 2001, 3-34.

[8] Fuisiak J., RYBICKI S., Numerical modelling of Dębina salt dome behaviour under influence on Betchatów open cast brown coal mine, Przegląd Geologiczny, 1997, 45, 9961000.

[9] Green G.E., Mikkelsen P.E., Measurement of ground movement with inclinometers, Proceedings of Fourth International Geotechnical Seminar on Field Instrumentation and In-Situ Measurement, Singapore, 1986, 235-246.

[10] Green G.E., Mikkelsen P.E., Deformation measurements with inclinometers, Transportation Research Record 1169. Transportation Research Board, Washington, 1988, 1-15.

[11] Gotowala R., HaŁuszczaK A., The late Alpine structural development of the Kleszczów Graben (Central Poland) as a result of reactivation of pre-existing regional dislocations, EGU Special Publication, 2001, 1, 137-150.

[12] HaŁuszczak A., Cenozoic dynamics of the Dębina Salt Dome, Kleszczów Graben, inferred from structural features of the Tertiary-Quaternary cover, Annales Societatis Geologorum Poloniae, 2004, 74, 311-318.

[13] Hochman A., Kolodziejczyk K., Kula A., Musielak W., OżóG J., Betchatów Brown Coal Mine. 25th anniversary. From public sector enterprise to joint stock company, Tekst Publishing House, Bydgoszcz, 2000.

[14] JAGÓRA E., SZwED-LORENZ J., Changeability analysis of main parameters of Betchatów brown coal open cast mine in western part of Szczerców field, National Institute of Mining Works, Wrocław University of Technology, 2005, 113, 87-98.

[15] MARTIN D., Long-Term Inclinometer Monitoring - An Update, Proc., 9th International Workshop on Accelerator Alignment, 26-29 September 2006, Stanford Linear Accelerator Center, USA, 2006.

[16] Mastej W., Bartuś T., Rydlewski J., Analysis of lithofacies cyclicity in the Miocene Coal Complex of the Betchatów lignite deposit, south-central Poland, Geologos, 2015, 21, 285-302.

[17] Pole Betchatów. Analiza deformacji wysadu solnego Dębina wraz $z$ aktualizacja budowy geologicznej $w$ rejonie wysadu i jego otoczenia oraz wytycznymi do projektowania konturu zbocza zachodniego, praca zbiorowa, ProGiG, Wrocław, październik 2009. 
[18] Segalini A., ChiapPoni L., CARINI C., Evaluation of a novel inclinometer device based on MMES technology through comparison with traditional inclinometers in landslide applications, Geophysical Research Abstracts, 2013, 15, EGU2013-1993.

[19] Segalini A., Chiapponi L., Pastarini B., Carini C., Automated Inclinometer Monitoring Based on Micro Electro-Mechanical System Technology: Applications and Verification, [in:] K. Sassa, P. Canuti, Y. Yin (eds.), Landslide science for a safer geoenvironment: methods of landslide studies, Springer International Publishing Switzerland, 2014, 595-600.

[20] Segalini A., Chelli A., Pastarini B., Giovanelli R., The Boschetto landslide: monitoring, numerical analysis and interpretation, Rendiconti Online Società Geologica Italiana, 2015, 35, 276-279.

[21] SŁOMKa T., WAGNER M., Charakter petrograficzny $i$ warunki sedymentacji wybranych kompleksów litologicznych profilu miocenu $w$ złożu węgla brunatnego Betchatów, Prace Geologiczne, 2000, 147, 1-122.

[22] Stark T.D., ChOI H., Slope inclinometer for landslides, Landslides, 2008, 3, 21-35.

[23] Widera M., Characteristics and origin of deformation structures within lignite seams - a case study from Polish opencast mines, Geological Quarterly, 2016, 60, 179-189.

[24] WieczoreK D., STOIŃSKI A., KRZYSZKOWSKI D., WACHECKA-KOTKOWSKA L., KRZYMIŃSKA J., The results of new studies of Quaternary sediments in the Kleszczów Graben, Szczerców Outcrop, Bełchatów Lignite Opencast Mine, Landform Analysis, 2015, 29, 63-67.

[25] ZDECHLIK R., Wpływ odwadniania KWB Betchatów na zmiany warunków hydrogeologicznych $w$ rejonie wysadu solnego Dębina, Prace Wydziału Geologii, Geofizyki I Ochrony Środowiska, AGH, 2004. 